\title{
Palaeomagnetic chronology of the evaporitic sedimentation in the Neogene Fortuna Basin (SE Spain): early restriction preceding the 'Messinian Salinity Crisis'
}

\author{
Jaume Dinarès-Turell $^{\mathrm{a}, \mathrm{b}, *}$, Federico Ortí $^{\mathrm{c}}$, Elisabet Playà ${ }^{\mathrm{c}}$, Laura Rosell $^{\mathrm{c}}$ \\ ${ }^{a}$ Paleomagnetic Laboratory Fort Hoofddijk, Budapestlaan 17, 3584 CD Utrecht, Netherlands \\ ${ }^{b}$ Institut de Ciències de la Terra Jaume Almera, CSIC, C/Lluís Solé i Sabarís, s/n, 08028 Barcelona, Spain \\ ${ }^{c}$ Departament de Geoquímica, Petrologia i Prospecció Geològica, Facultat de Geologia, Universitat de Barcelona, \\ Zona Universitària de Pedralbes, 08071 Barcelona, Spain
}

Received 28 December 1998; revised version received 17 May 1999; accepted 20 May 1999

\begin{abstract}
The magnetostratigraphic study of the evaporitic Río Chicamo section $(240 \mathrm{~m})$ in the Neogene Fortuna Basin (Murcia, southeast Spain) has identified the record of five magnetozones. The most probable correlations with the standard geomagnetic polarity time scale (GPTS) imply that the marine evaporitic sedimentation of this basin was not coeval with the Messinian evaporites of the Sorbas Basin (Almeria, southeast Spain) and the Caltanissetta Basin (central Sicily) (assigned to the reverse Chron C3r, late Messinian by Gautier et al., 1994). The marine evaporites and diatomites from the Fortuna Basin are older (late Tortonian to early Messinian) than the evaporites of those basins. The chronological framework for the sedimentation in the Fortuna Basin together with the isotopic data from the sulphates in these evaporitic units indicate the following. (1) Restriction and confinement in the basin initiated as early as uppermost Tortonian, leading to deposition of evaporites under mixed (marine-continental) conditions. (2) The subsequent sedimentation of marine evaporites and diatomites in this basin occurred in a period between the Tortonian and Messinian transition and the early Messinian: the onset of this sedimentation pre-dates similar sediments of restricted marine environments in the eastern Betics basins, and possibly of the western Mediterranean region also. (3) Episodes of restriction and reflooding in the basin would have occurred in response to periodic fluctuations of the oceanic level under local tectonic controls. In the Fortuna Basin, the global base level drop associated with the 'late Messinian Salinity Crisis' was recorded by the progradation of alluvial fans leading to thick clastic deposits overlying the youngest evaporites. These observations hint to: (a) the peculiar characteristics and sensitiveness of some of the marginal intramontane basins in the eastern Betics to reflect structural controls framed in the late Neogene global climatic changes; and (b) the diachronism of the beginning of the marine evaporitic deposition in the Mediterranean region linked to the salinity crisis during the Messinian. (C) 1999 Elsevier Science B.V. All rights reserved.
\end{abstract}

Keywords: magnetostratigraphy; Mediterranean; eastern Betics: evaporites; salinity crisis; Messinian

\footnotetext{
* Corresponding author. Present address: Istituto Nazionale di Geofisica, Via di Vigna Murata 605, 0143 Roma, Italy. Fax: +39 06504 1181; E-mail: dinares@marte.ingrm.it
} 


\section{Introduction}

The Upper Miocene of the Mediterranean region is characterised by the restriction that affected the area leading to large-scale deposition of evaporites (the so-called 'Messinian Salinity Crisis'). The hydrologic changes which were involved are documented in the sedimentary record by a sequence of marine marls, diatomite-bearing deposits (Tripoli Formation), shallow water carbonates (Calcare di Base), evaporites (Lower Evaporites and Upper Evaporites) and brackish deposits (LagoMare) (Cita et al., 1978; Hsü et al., 1978; Rouchy, 1982; Rouchy and Saint-Martin, 1992). The study of the Tortonian/Messinian deposits from the Neogene Mediterranean basins and their relation with the 'Messinian Salinity Crisis' has been addressed by many authors since the 1970s. However, details of this event and the precise timing and contemporary deposition of evaporites for the whole Mediterranean region remains one of the major problems still unresolved (Rouchy and Saint-Martin, 1992; Kastens, 1992). The Neogene basins in the eastern Betics (southeast Spain) contain a remarkable record of Upper Miocene and Pliocene sediments and are assumed to have constituted the Betic Corridor, a gateway that connected the western Mediterranean Sea with the Atlantic Ocean (Montenat, 1973a,b; Müller and Hsü, 1987; Sanz de Galdeano and Vera, 1992). Therefore, these basins offer a unique opportunity to evaluate the ongoing tectonic processes, and the superimposed palaeoclimatic (glacio-eustatic sea level fluctuations) component that progressively closed the marine gateways during the Messinian and caused a complete isolation of the Mediterranean. The Neogene evaporitic sedimentation in the eastern Betics occurs in both marine and continental settings following the structural and palaeogeographic evolution of the chain. Rouchy (1982) distinguishes two zones in this area: (1) an internal or proximal zone, relatively close to the actual Mediterranean coast, where the evaporitic sedimentation occurred in marine settings and is characterised by the cyclic character and predominance of primary selenetic facies (i.e. San Miguel de Salinas Basin); and (2) an external or distal zone where the evaporitic sedimentation initiated in marine conditions and ended in continental environments. In this external zone, the evaporitic facies are usually made up of nodular laminated or banded secondary gypsum (i.e. Lorca and Fortuna basins) (Ortí et al., 1993). Additionally, there exists a third more external zone, extending along the Prebetic sector, where the evaporitic sedimentation occurred in continental conditions since the Tortonian (i.e. Campo Coy and Minas de Hellín basins).

Although some attempts have been made to directly date the 'Messinian' evaporites and the underlying sediments in the Mediterranean realm by means of magnetostratigraphy (Langereis and Dekkers, 1992; Gautier et al., 1994; McClelland et al., 1996; Krijgsman et al., 1996; Dinarès-Turell et al., 1998; Butler et al., 1999), the chronology of the Mediterranean Late Miocene sedimentary sequence is still lacking sufficient accuracy and is the subject of discrepancies. Nevertheless, the onset of the evaporite deposition in the Mediterranean area is generally thought to occur in the early Gilbert. This is supported by the magnetostratigraphy of several sections from the Caltanissetta Basin in Sicily, in addition to one section from the Sorbas Basin in southeastern Spain (Gautier et al., 1994). Both at Sicily and at the Sorbas Basin the evaporitic deposition started in the early part of Chron $\mathrm{C} 3 \mathrm{r}$ at $\sim 5.7$ $\mathrm{Ma}$ and remained within this chron, providing a total duration of $\sim 0.4 \mathrm{Ma}$. In agreement with this age is the cyclostratigraphic framework of the standard Mediterranean Messinian evaporitic succession that suggests that the onset is younger than $6.0 \mathrm{Ma}$, and probably even post-dates the Gilbert/Chron 3 boundary which is tentatively dated astronomically at 5.955 Ma (Hilgen et al., 1995). Hilgen et al. (1995) have further noted, in favour of the upper Messinian onset, its close coincidence with the most extreme glacial stages TG 20 and 22 in the high-resolution stable isotope record of ODP Site 846 from the equatorial Pacific Ocean (Shackleton et al., 1995) and Atlantic Morocco (Hodell et al., 1994), suggesting at least a partial glacio-eustatic control on the final isolation of the Mediterranean during latest Miocene time.

Challenging these evidences, McClelland et al. (1996) have presented preliminary magnetostratigraphies from two Sicilian sections that include the Calcare di Base and/or the sediments underneath (Tripoli Formation). By comparing variations in the sediment rate derived from the alternative matches with the GPTS with the lithologic features these 
authors arrived at their favoured correlation. Such correlation not only places the onset of the Calcare di Base (and hence the evaporitic sedimentation) to an older age (early Messinian) than previously estimated, but also implies some diachroneity of facies along different areas. In this line, Butler et al. (1995) consider a series of thrust-top, perched subbasins in the northern part of the Sicilian Caltanissetta Basin to have experienced different degrees of marine stagnation and consequently to have acquired their evaporitic fills at different times. This model is further discussed by Butler et al. (1999) who have extended their studies through the Caltanissetta Basin. Although these challenging Sicilian magnetostratigraphic correlations are not fully substantiated, they pose a certain threat to the more accepted belief of the generalised onset of evaporitic sedimentation in the upper Messinian.

In this paper, we present new magnetostratigraphic results from a section in the Neogene Fortuna Basin from southeast Spain. This contribution builds on the increasing interest in reconciling the geology of the different circum-Mediterranean outcrops in relation to the onset of the salinity crisis. The presented results enlarge the existing chronological data set for correlating the main sedimentary events in the Mediterranean during the late Neogene, and emphasise the particular record of the Upper Miocene restricted conditions in a marginal intramontane basin.

\section{The Fortuna Basin: geological setting and stratigraphy}

The Fortuna Basin in southeast Spain is one of the numerous intramontane basins that developed in the eastern Betics since the early Tortonian (Montenat, 1977; Sanz de Galdeano, 1990; Montenat et al., 1990; Sanz de Galdeano and Vera, 1992) (Fig. 1). These basins developed along a large $(>250 \mathrm{~km})$ left-lateral shear zone (Trans-Alboran shear zone) trending NE-SW from Alicante to Almeria cities, which represents one of the main structural features of the western Mediterranean (Montenat and Ott d'Estevou, 1990).

The Fortuna Basin (or the Fortuna-Mula Basin) lies on the boundary of the Internal Zones (Betic) and the External Zones (Subbetic) of the Betic Cordillera. Its evolution was controlled by two major faults of the regional NE-SW shear zone, the North Betic-Crevillente Fault (de Smet, 1984) to the north and the Alhama de Murcia Fault (Montenat, 1973a) to the south.

Since the early work of Montenat (1973a), many other authors (Santisteban, 1981; Müller, 1986; Müller and Hsü, 1987; Lukowski, 1987; Ortí et al., 1993) have studied the sedimentary record of the Fortuna Basin and have defined different stratigraphic units within the basin infill sediments. In general, the sedimentary infill can be grouped into three main units: (1) a lower marine unit about $500-600 \mathrm{~m}$ thick consisting of turbidites and pelagic marls (Fortuna Marls Formation); (2) a regressive evaporitic sequence with gypsiferous marls, diatomites, massive gypsum and conglomerates (Río Chicamo Formation); and (3) an upper unit including a variety of facies but mainly continental alluvial to lacustrine evaporitic deposits (Rambla Salada Formation). In detail, however, variations to this general pattern can be observed, especially on the northern margin of the basin where different reef complexes exist, and lateral conglomeratic equivalents to the evaporitic bodies are present (Santisteban, 1981; Lukowski et al., 1988; Lukowski and Poisson, 1990). Seemingly, the southeastern margin of the basin is characterised by a set of alluvial fans which spread into the basin during the Late Miocene as a consequence of a basement uplift along this margin that created emerged source reliefs to the east of the Alhama de Murcia Fault (Montenat, 1973a; Gauyau et al., 1977).

A confined Neogene magmatic activity exists within the eastern Betics which is closely related to the Trans-Alboran shear zone (Montenat, 1977; Bellon et al., 1983; Hernandez et al., 1987). The volcanic activity is distributed into various 'belts' that migrate northwestwards during Late Miocene time. In general, three main volcanic groups are distinguished: (1) the Cabo de Gata group located to the south, which includes different calc-alkaline sequences dated as late Burdigalian, (2) the Mazarrón group located in a central position, which is another calc-alkaline sequence with high $\mathrm{Al}$ content, its age being late Tortonian, and (3) the Lamproites (also known as Fortunites) group to the north, which in- 


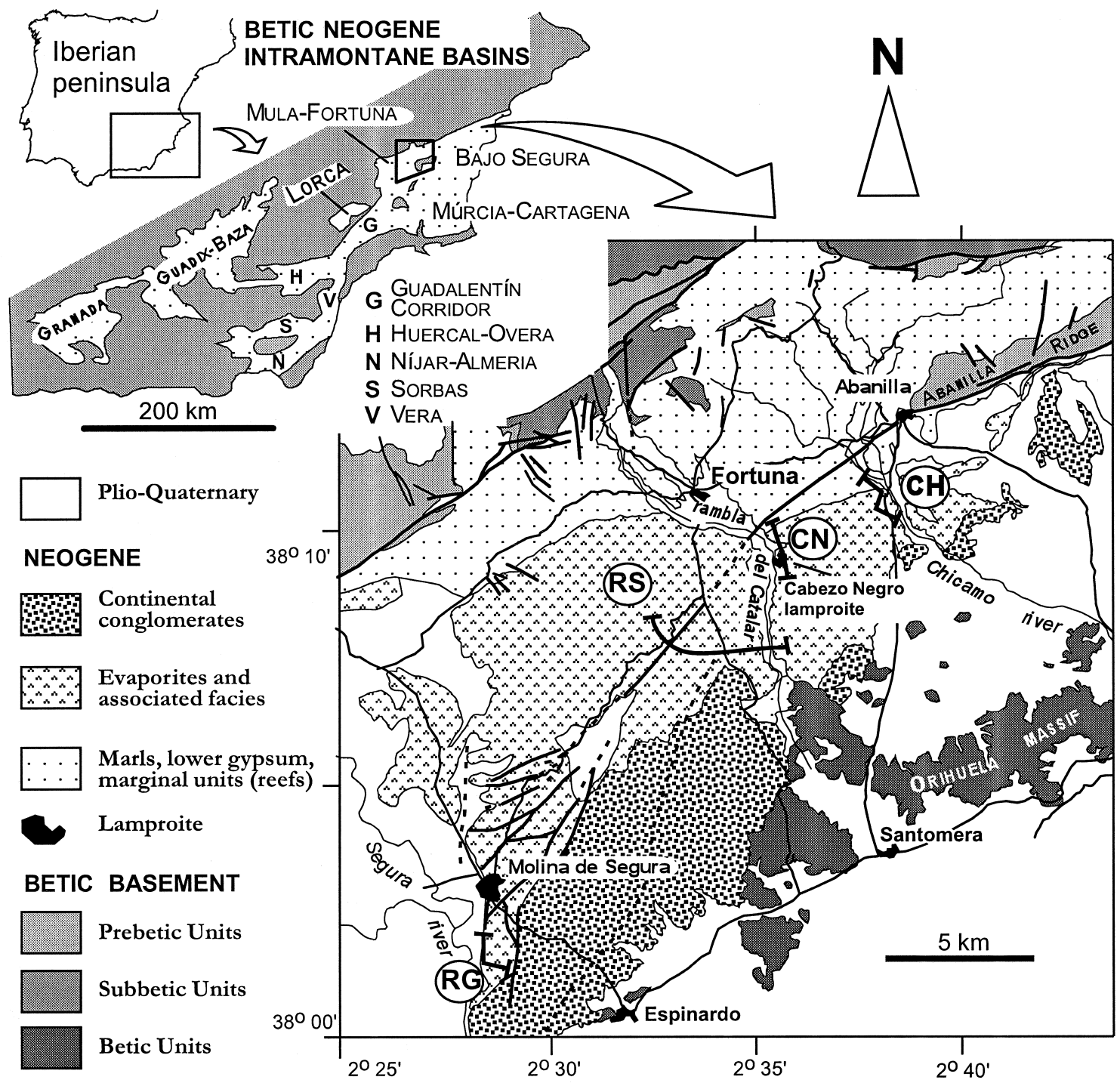

Fig. 1. Location of the Fortuna Basin in the eastern Betics (inset) and geological sketch map with location of sections (adapted from Lukowski, 1987; Montenat and Ott d'Estevou, 1990). $R G=$ Ribera village; $R S=$ Rambla Salada; $C N=$ Los Cabezos Negros; $C H=$ Río Chicamo.

cludes a variety of dark glass-rich high- $\mathrm{K}$ and $\mathrm{Mg}$ rocks and coeval cinerites of mainly Messinian age.

Dating of the different formations in the Fortuna Basin has been contradictory, and therefore the associated palaeogeographic and sedimentological interpretations have been controversial. Montenat (1973a) assigned a Tortonian age to the marine marls (Fortuna Marls Formation) and a latest Tortonian to early Messinian age to the evaporites.
Santisteban (1981) locates the Tortonian-Messinian $(\mathrm{T} / \mathrm{M})$ boundary at the base of the evaporitic sedimentation. A biostratigraphic revision accounting for new planktonic biozonation standards in the Mediterranean (d'Onofrio et al., 1975) led Lukowski et al. (1988) to propose a Messinian age for the marine marls and the main coral reefs, and a late Messinian age for the evaporites. However, the first occurrence (FO) of Globorotalia conomiozea, nowadays 
widely used as a bioevent defining the T/M boundary (Iaccarino, 1985), has not been reported in the Fortuna Basin. Yet, Sierro et al. (1992) locate the Fortuna Marl Formation in the middle Messinian on the basis of fluctuations in the Neogloboquadrina acostaensis group and the presence of Globigerina multiloba. Other authors studying the Fortuna Basin have assumed its chronology by correlating some sedimentological/geochemical features on regional scales. Thus, Müller and Hsü (1987), and Müller and Schrader (1989) consider the evaporites to be late Messinian in correlation with the well-known gypsum deposits (Lower Evaporites and Upper Evaporites) of the Mediterranean basin. We must emphasise, however, that the postulated Messinian age for the Fortuna Marl Formation is not substantiated by an accurate chronology.

\section{The evaporite units}

The stratigraphic scheme used in this work builds up from earlier studies in the basin (i.e. Montenat, 1973a; Santisteban, 1981; Müller, 1986; Lukowski, 1987) and has been outlined in Ortí et al. (1993) and Playà (1998). A lithostratigraphic correlation between some representative sections of the evaporitic succession in the northeastern part of the Fortuna Basin is presented in Fig. 2.

The oldest evaporitic unit (Lower Gypsum) is located in the upper Fortuna Marl Formation. Its distribution in the basin is irregular and the thickness varies from 0 to $20 \mathrm{~m}$ (RS and $\mathrm{CN}$ sections, Fig. 2). Upwards in the stratigraphic succession is the second evaporitic unit, which is $50-60 \mathrm{~m}$ thick and outcrops from the northeastern part of the basin towards the southwest (Chicamo Gypsum, previously denominated Tale Gypsum by Müller, 1986). The Chicamo Cycles, consisting of 6 to 7 diatomitic-evaporitic cycles, overlie the Chicamo Gypsum. The individual cycles are a few metres thick and the unit can reach a maximum of $40 \mathrm{~m}$. Overlying the Chicamo Cycles is the Ribera Gypsum which is well developed in the Segura River area (section RG, Fig. 2). However, this unit thins out laterally through irregular outcrops and becomes absent near Abanilla, in the northeast, and in the Librilla area in the southwest. The uppermost evaporitic unit is the Rambla Salada Gypsum
(Rambla Salada Formation, Müller, 1986), which has a thickness ranging from a few metres to $>100 \mathrm{~m}$ and varying distribution in the basin. The evaporitic facies are dominant in the Abanilla area to the northeast whilst the formation becomes detrital and very thick in the Segura River area to the southwest and towards the Librilla area and along the Guadalentin Corridor (Fig. 1). In the southern area, the evaporitic beds are thin and restricted to the lower part of the formation which is characterised by a $>100 \mathrm{~m}$ thick succession of continental sands and conglomerates.

The combined study of oxygen $\left(\delta^{18} \mathrm{O}\right)$, sulphur $\left({ }^{34} \mathrm{~S}\right)$ and strontium $\left({ }^{87} \mathrm{Sr} /{ }^{86} \mathrm{Sr}\right)$ isotopic composition of the different gypsum units has enabled the determination of the nature (marine, continental or mixed) of the brines that lead to the sulphate precipitation (Playà et al., 1995; Playà, 1998). As a result, and contrasting with earlier interpretations given for this basin (Rouchy and Pierre, 1979; Utrilla, 1989), the evaporitic sedimentation in continental and transitional marine-continental environments was frequent and evidenced by the important quantity of recycled Triassic gypsum in the Neogene evaporites. The Lower Gypsum displays a varying isotopic composition with values dispersed from the typical continental Triassic ones to the marine Tertiary values. The Chicamo Gypsum has isotopic compositions framed within the Triassic values, indicating that precipitation occurred from brines arising from the dissolution of continental evaporites. In contrast, data from both the Chicamo Cycles and the Ribera Gypsum indicate precipitation from marine brines exclusively. This indicates a permanent oceanic connection at the time of deposition of these units. Finally, the Rambla Salada Gypsum with sulphate isotopic compositions in agreement with the Triassic values marks the final continentalisation of the evaporitic basin.

\section{The Río Chicamo section: sampling and methods}

The Río Chicamo $(\mathrm{CH})$ section is located in the northeastern part of the Fortuna Basin about $4 \mathrm{~km}$ south of the Abanilla village (Fig. 1). Bedding is tilted $20-25^{\circ}$ toward the southeast. The $240 \mathrm{~m}$ sampled section begins with $70 \mathrm{~m}$ of marine grey- to 


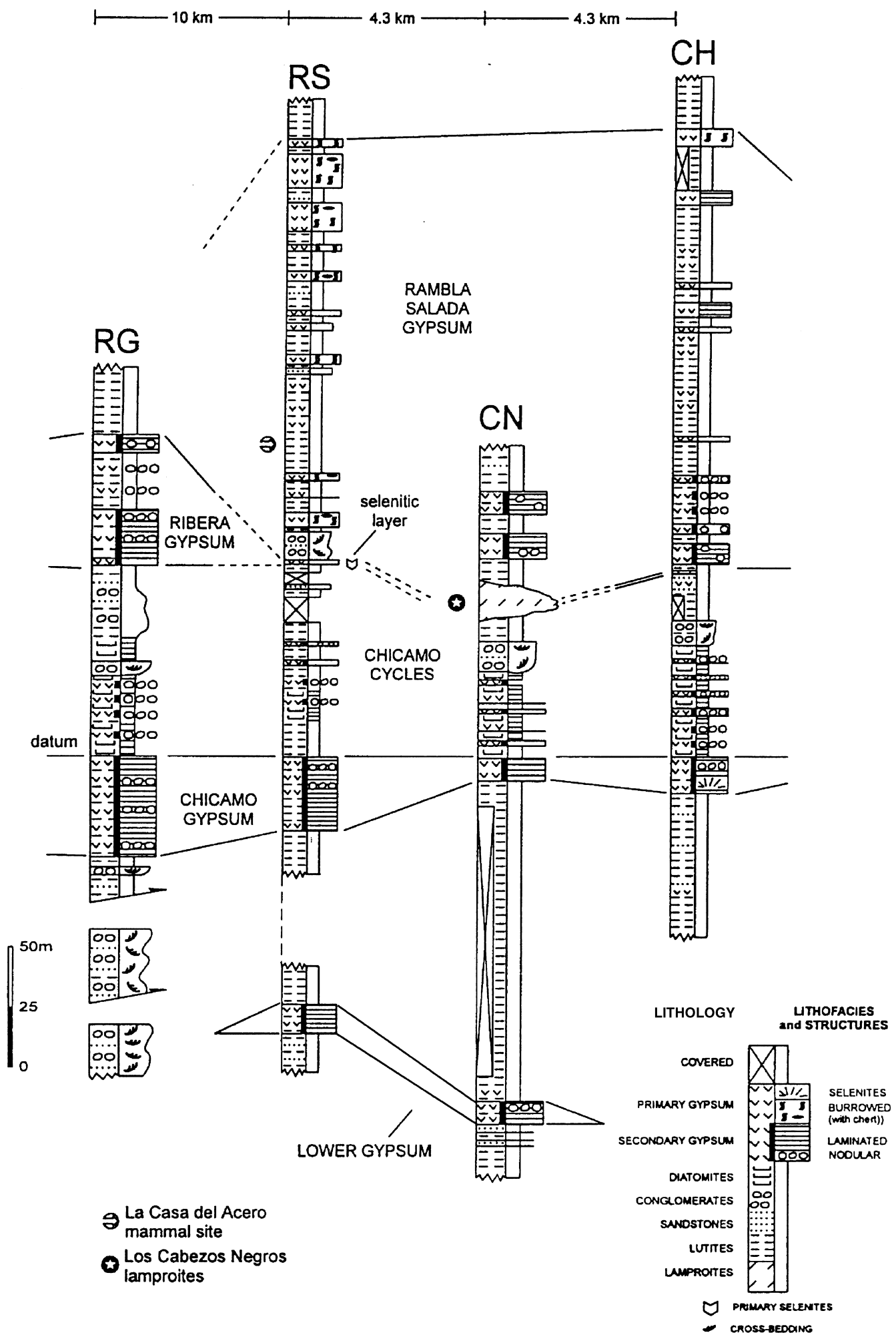


blue-coloured marly clays at the base, with few beds of sandy layers and a few thin intercalations of reddish silty horizons (Fig. 3). These marly clays represent the upper part of the Fortuna Marls Formation. Overlying these marls there is a $15 \mathrm{~m}$ thick gypsum unit (the Chicamo Gypsum) with interbedded marly horizons (in this section the Lower Gypsum is absent, although this unit crops out to a distance of about $400 \mathrm{~m}$ to the northeast). Immediately above the Chicamo Gypsum, there are up to six alternations of diatomite layers associated with laminated marls and gypsum beds. These are the diatomite-gypsum Chicamo Cycles, which were first described in detail by Müller, 1986. The gypsum layer forming the top of the fourth cycle is a typical carbonate-gypsum stromatolite. Reddish conglomerates and sandstones of marine origin, up to $25 \mathrm{~m}$ thick, are lying unconformably on the top of the Chicamo Cycles. Overlying these clastic sediments, the Ribera Gypsum is represented by a $\sim 1 \mathrm{~m}$ thick layer of nodular gypsum; in a short distance toward the southwest, this layer becomes thicker and has been quarried. The Ribera Gypsum is overlain by a thick (>150 m) unit, the Rambla Salada Gypsum, which is characterised in this area by an alternation of gypsum, clay, and marly-clay layers.

A total of 200 samples were collected in the 90 sampling sites distributed along the $240 \mathrm{~m}$ of the studied profile. Samples were usually cored $(2.54$ $\mathrm{cm}$ in diameter) with a portable gasoline-powered drill although hand samples were also collected in a few instances. In general, sampling spacing was less than $3 \mathrm{~m}$. Samples were subdivided in the laboratory into standard specimens $(2.2 \mathrm{~cm}$ in length) for palaeomagnetic analysis. Sampled lithologies include primarily greyish marls; sandy, gypsiferous and diatomitic marls and marginally some reddish silts and silty sandstones. The Natural Remanent Magnetisation (NRM) and its evolution upon stepwise thermal demagnetisation (TH) were measured in a double-shielded GM400 three-axis cryogenic magnetometer (CCL). A Schonstedt TSD-1 oven with a residual field of $10 \mathrm{nT}$ was used for thermal demagnetisation. In general, between 10 and 15 incremental temperature steps $\left(30-50^{\circ} \mathrm{C}\right.$ steps) were applied in each sample from room temperature up to a temperature where the remanence intensity falls below the sensitivity of the magnetometer or until spurious behaviour precluded further demagnetisation. Characteristic remanent magnetisations (ChRM) were computed by Principal Component Analysis (Kirschvink, 1980) on the orthogonal demagnetisation plots (Zijderveld, 1967). The initial susceptibility, its anisotropy and its variations upon thermal cleaning were measured on a Kappabridge (KLY-2) instrument. The mean declination and inclination of the ChRM component of each sample has been used to derive the latitude of the Virtual Geomagnetic Pole (VGP). This parameter has been used as an indicator of the polarity (normal polarity for positive VGP latitudes and reverse polarity for negative VGP latitudes).

\section{Palaeomagnetic results}

The NRM intensity of the studied rocks ranges from $\sim 2 \times 10^{-2} \mathrm{~mA} / \mathrm{m}$ to $\sim 50 \mathrm{~mA} / \mathrm{m}$ although the bulk of samples present values around $0.1 \mathrm{~mA} / \mathrm{m}$ (Fig. 4). The highest NRM intensities correspond to some red silts. Low-field magnetic susceptibility ranges from $\sim 20 \times 10^{-6}$ SI to $\sim 1500 \times 10^{-6}$ SI. The linear correlation between NRM intensity and susceptibility in the reddish lithologies (Fig. 4) suggests that the latter is likely to be controlled by the ferromagnetic mineral phases, although NRM alone may not represent the best estimate for the ferromagnetic content. Conversely, in most greyish marls and sands the paramagnetic phases (usually clays in these lithologies) are probably the main contributors to the susceptibility.

The anisotropy of magnetic susceptibility (AMS) was measured in pilot specimens distributed along the studied section in order to gather information

Fig. 2. Lithostratigraphic correlation between some representative sections of the evaporitic succession in the Neogene Fortuna Basin (see Fig. 1 for location of sections). Datum: first diatomite layer of the Chicamo Cycles unit (adapted from Playà, 1998). The Los Cabezos Negros lamproite dated at 6.1 $\pm 0.3 \mathrm{Ma}$ (Bellon et al., 1983) and the mammal site of Casa del Acero (fauna from biozone MN12) (Agustí et al., 1985) are also shown on sections CN and RS, respectively. 

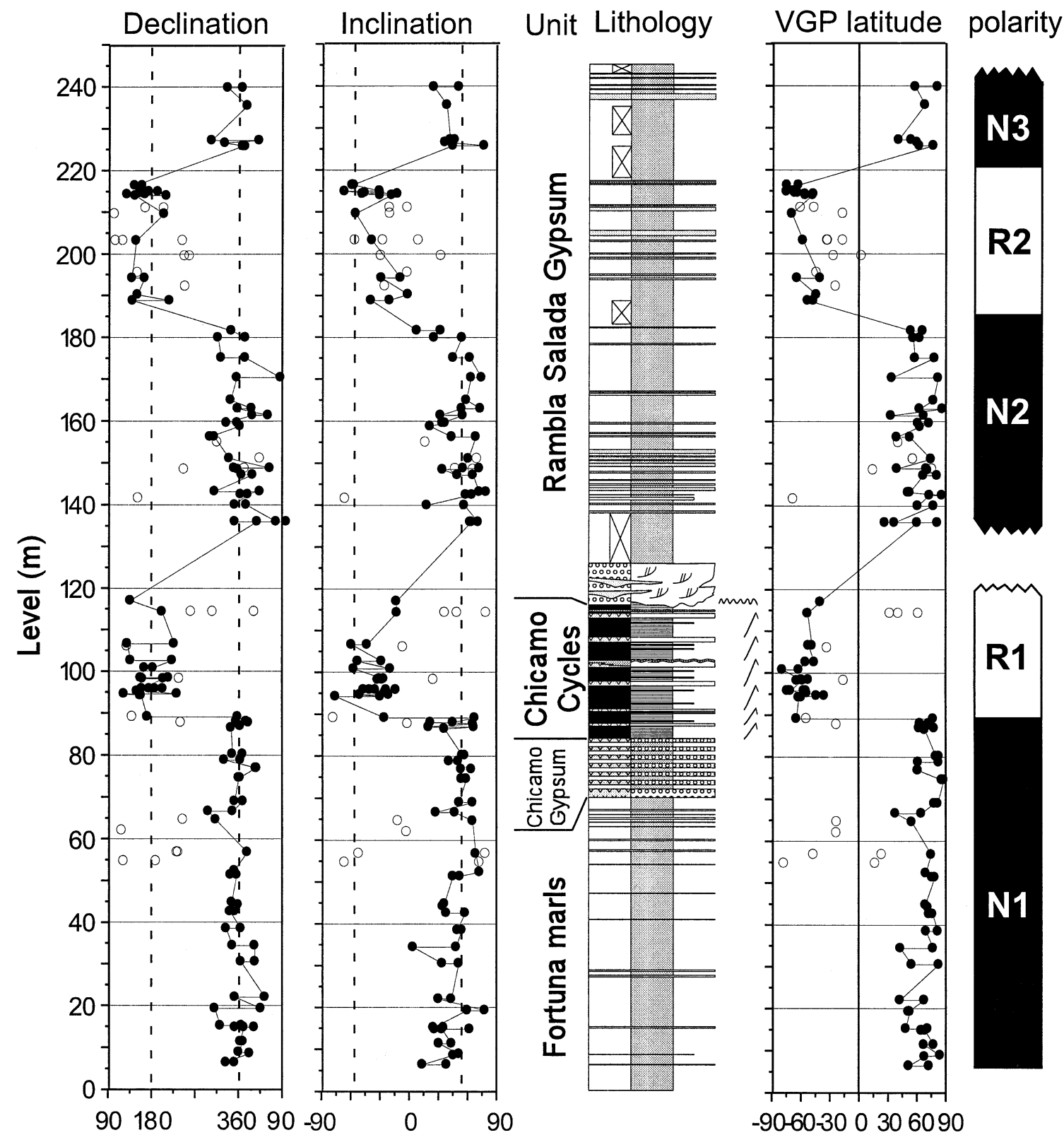

Fig. 3. Stratigraphy and magnetostratigraphy of the Río Chicamo section. Declination and inclination represent the bedding-corrected ChRM directions. Dots represent reliable directions used for the magnetostratigraphy and circles denote rejected unreliable directions.

about the nature of the magnetic fabric that would complement the magnetostratigraphic study. AMS can potentially reflect a sedimentary fabric or a tectonic-induced petrofabric even in weakly deformed areas. The three principal susceptibility axes $\left(K_{\max }\right.$, $K_{\text {int }}$ and $\left.K_{\min }\right)$, defining the ellipsoid of magnetic susceptibility, are plotted in Fig. 5a. It can be observed that $K_{\min }$ clusters around a subvertical position that corresponds to the bedding pole although it has some tendency to be dispersed along a NNWSSE direction. $K_{\text {int }}$ and $K_{\max }$ also appear to be grouped with somewhat more scatter than $K_{\text {min }}$ and 


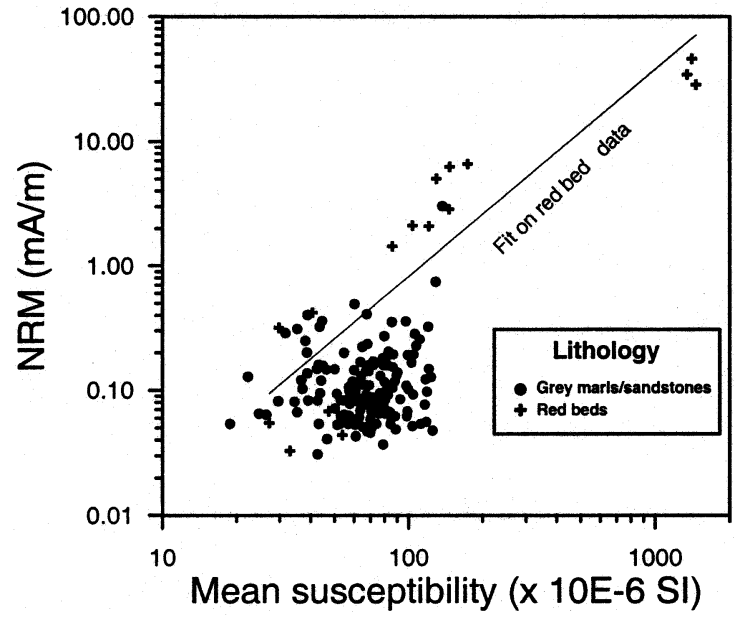

Fig. 4. NRM intensity plot versus low-field magnetic susceptibility showing higher values and a linear correlation for the reddish lithologies.

are contained within the bedding plane. In sedimentary rocks it is common to observe oblate ellipsoids with minimum axis subparallel to the bedding pole and maximum principal axis $K_{\max }$ (the direction of the maximum grain elongation when AMS is controlled by the particle shape anisotropy) grouped and contained in the bedding plane. Such fabrics are interpreted to reflect the dominant palaeocurrent during deposition. In the $\mathrm{CH}$ section the relationships of bedding with the magnetic ellipsoid seem to follow the outlined model (Fig. 5). The grouping of $K_{\max }$ in the ENE-WSW direction could therefore be interpreted as a direction containing the depositional palaeocurrent. However, we note that prolate ellipsoids also occur in addition to dominant oblate shapes (Fig. 5b). Moreover, there appears not to be a vertical variation of the direction of $K_{\max }$ along the $\mathrm{CH}$ section which will be evidence of changing depositional conditions and hence of the sedimentary origin of the magnetic fabric. Reddish silts and sandstones only show a higher anisotropy degree $\left(P^{\prime}\right)$ (Fig. 5b). Consequently, given all the aforementioned observations, the possibility of a tectonic overprint of the AMS fabric observed in the $\mathrm{CH}$ section cannot be ruled out.

It is known that one of the first effects of deformation in weakly deformed rocks is to align the $K_{\max }$ perpendicular to the compression direction of strain and subsequently to scatter the $K_{\text {int }}$ and $K_{\min }$ axis along a girdle (i.e. Parés and Dinarès-Turell, 1993). The lineation observed in the $\mathrm{CH}$ section is consistent with the one observed in Pliocene-Quaternary alluvial sediments from the northern margin of the Bajo Segura Basin just tens of $\mathrm{km}$ northeast of the $\mathrm{CH}$ section (Dinarès-Turell et al., 1995). In that study independent evidence for a NNW-SSE compression component from dissolution poles measured on clasts was available and related to the regional deformation along the Alicante-Crevillente structural lineation. The $\mathrm{CH}$ section is located near the ENEWSW Sierra de Abanilla Fault structure (equivalent structure to the Alicante-Crevillente lineament within the Trans-Alboran shear zone) (Fig. 1), and hence could represent an analogous deformational scenario. However, a more specific sampling devoted to anisotropy studies would be desirable before establishing any conclusive interpretation of the AMS at the $\mathrm{CH}$ section.

Generally, two specimens per sampling level were subjected to progressive stepwise thermal demagnetisation $(\mathrm{TH})$. Maximum unblocking temperatures in the greyish lithologies (marls, diatomitic and sandy marls and fine sandstones) reach $450-500^{\circ} \mathrm{C}$ (Fig. 6a,c,d,e,g,i) although in some cases complete demagnetisation is precluded by spurious behaviour due to alterations upon heating at high temperature (Fig. 7). These maximum unblocking temperatures indicate that magnetite (Ti-rich magnetite?) is likely the main contributor to the NRM in these lithologies. The fine interbedded reddish silts and silty sandstones show maximum unblocking temperatures higher than $580^{\circ} \mathrm{C}$ (Fig. 6b,f,h) consistent with the presence of hematite as magnetic carrier. The $\mathrm{TH}$ demagnetisation of all studied rocks reveals a twocomponent NRM in addition to a small viscous component removed usually at $100^{\circ} \mathrm{C}$ (Fig. 6). The low temperature component (removed below $300-350^{\circ} \mathrm{C}$ in the greyish lithologies and up to $500^{\circ} \mathrm{C}$ in the reddish ones) corresponds in geographic coordinates to the present-day field dipole and is therefore regarded as a secondary overprint. The Characteristic Remanent Magnetisation (ChRM) displayed as the linear paths trending towards the origin of the orthogonal demagnetisation diagrams (Fig. 6), is removed up to the maximum unblocking temperatures outlined above and presents both normal and reversed polarities. The normal and reversal polarity sets are 

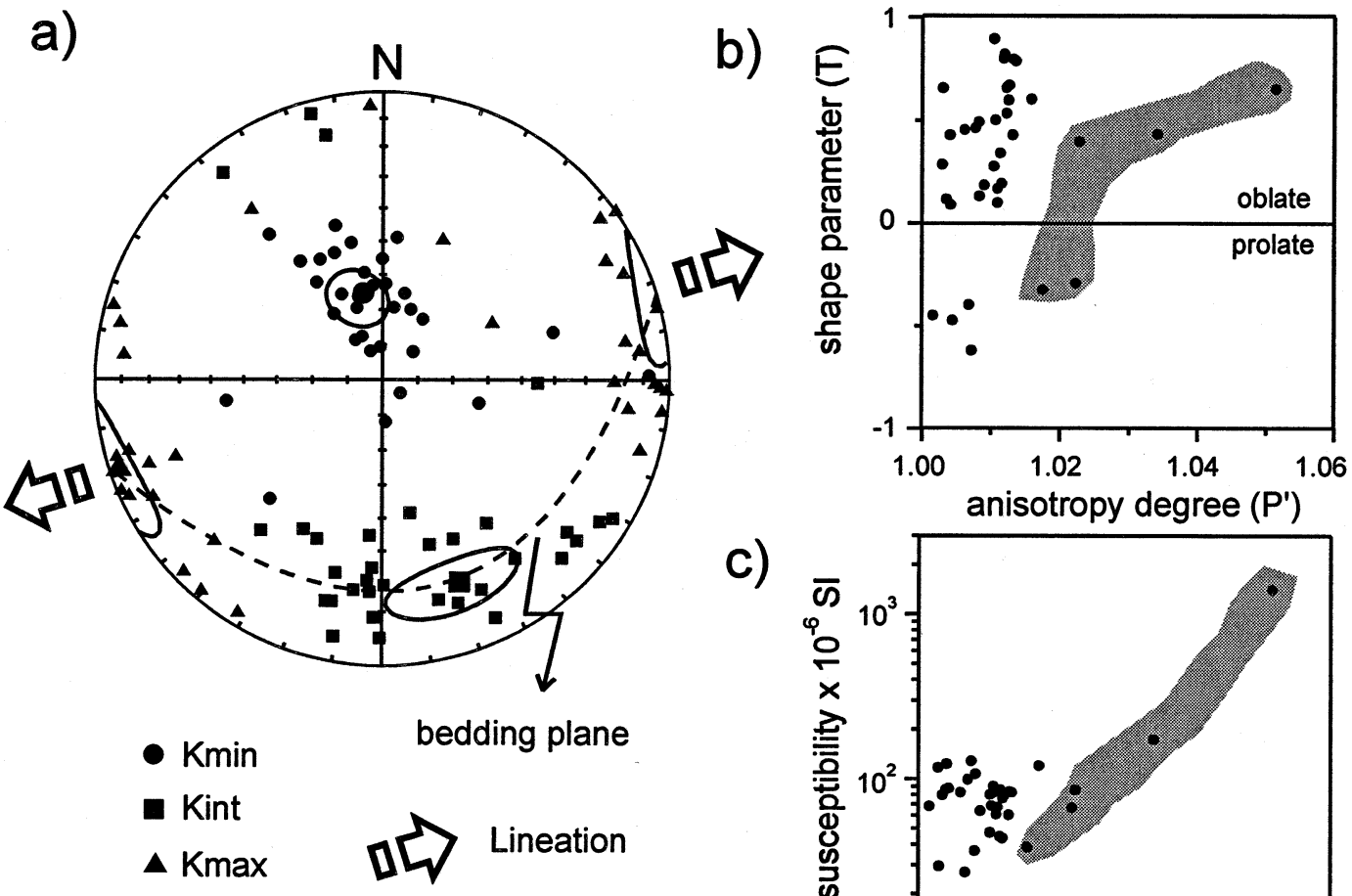

C)

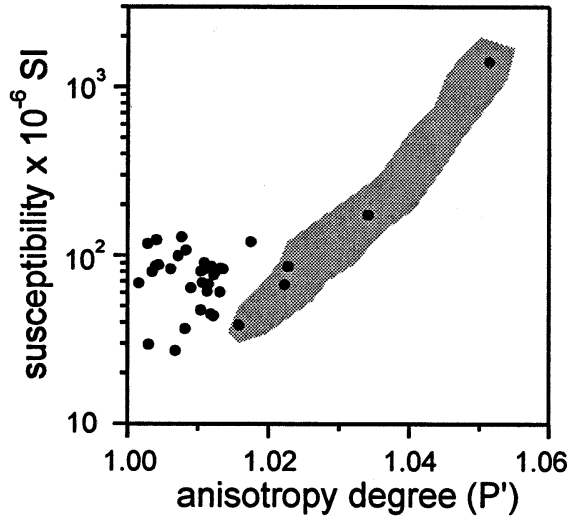

Fig. 5. (a) Stereonet projection of the AMS principal susceptibility axis: the elliptical error limits for each mean direction is also indicated. (b) Hrouda-Jelinek anisotropy plot showing the shapes of the AMS ellipsoids. (c) Susceptibility versus anisotropy degree ( $\left.P^{\prime}\right)$ diagram. Shaded area in (b) and (c) includes data from the reddish lithologies.

not perfectly antipodal (an angle of $15^{\circ}$ is observed between the respective mean directions), and result in a negative reversal test (McFadden and McElhinny, 1990). The lack of perfect antipodality could be partly explained by an uncompleted removal of the secondary overprint. This would especially bias the reverse ChRM directions towards shallower inclinations with respect to the normal ones as can be observed in the $\mathrm{CH}$ section (Fig. 8).

The primary nature of the ChRM is supported by the presence of a dual-polarity ChRM in addition to the low temperature present-day field overprint, and a more consistent overall inclination after bedding correction with the expected Miocene palaeoinclination $\left(\sim 55^{\circ}\right)$ (Fig. 8 ); changes in polarity do not seem to be lithologically controlled.

The VGP latitude derived from the ChRM directions yields a succession of five magnetozones (three normal and two reverse) that have been labelled from oldest to youngest as N1-R1-N2-R2-N3 (Fig. 3). In the central part of the section, an unexposed interval above the conglomerates renders an unsampled interval of $19 \mathrm{~m}$.

\section{Magnetostratigraphic correlation and discussion}

\subsection{Biostratigraphic and numerical dating constraints}

The Río Chicamo section under study has not furnished any biostratigraphy. However, micromammal fauna assigned to biozone MN12 have been described from a site (La Casa del Acero site) located in the Rambla Salada (RS) (Fig. 2) at about $10 \mathrm{~km}$ from the 


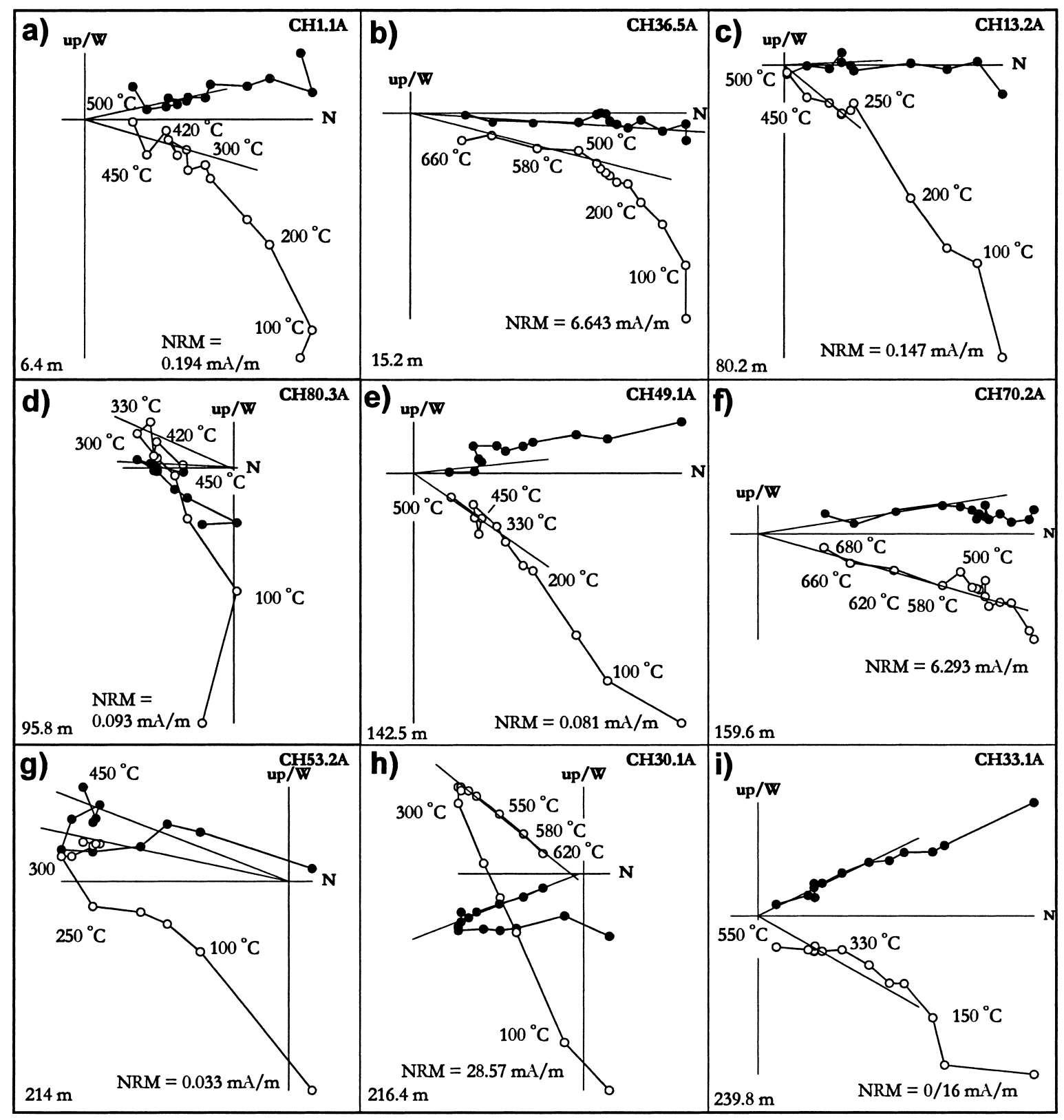

Fig. 6. In-situ orthogonal plots of stepwise thermal demagnetisation of representative samples from the Río Chicamo section (a, c, e, g, i: greyish marls and fine sandstones; b, f, h: reddish silts and silty sandstones; d: diatomitic marl). The stratigraphic position of each sample is noted in the lower left corner of the diagrams. Solid (open) symbols denote projections onto the horizontal (vertical) plane.

Río Chicamo (CH) section (Agustí et al., 1985). The site is located about $40-50 \mathrm{~m}$ upward from the base of the Rambla Salada Gypsum. Lukowski (1987) also refers to the presence of fauna attributed to the MN12 and MN13 continental biozones at different points of the Fortuna Basin. However, there is no consensus about the exact age of the MN12/MN13 boundary and hence of the MN12 fauna itself. Steininger et 


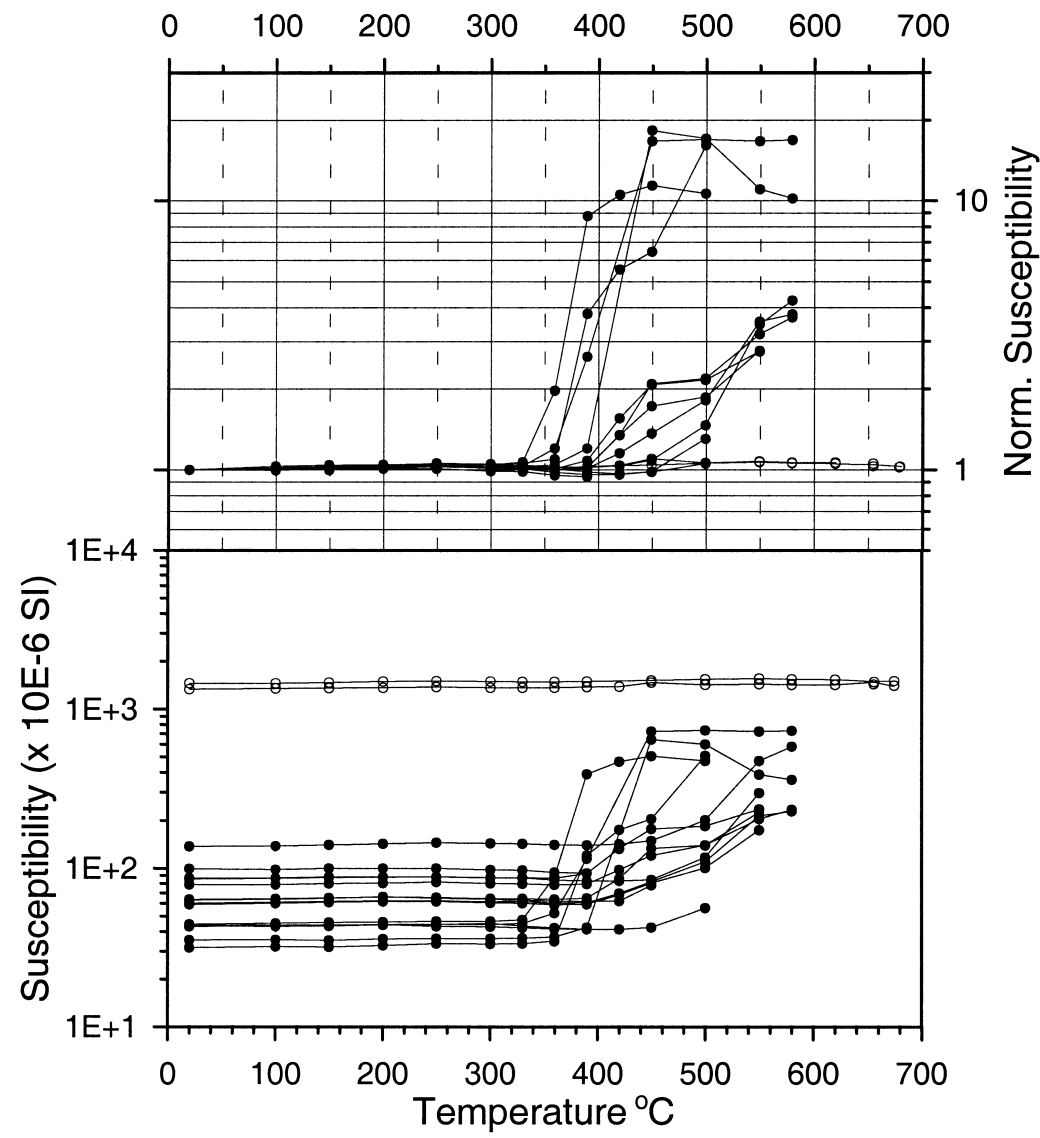

Fig. 7. Normalised (upper diagram) and raw (lower diagram) low-field susceptibility variations upon thermal treatment of representative lithologies showing a substantial increase at about $350-400^{\circ} \mathrm{C}$ in the greyish lithologies (dots) and almost no variation in the reddish samples (circles).

al. (1996) place the MN12/MN13 boundary close to the Tortonian/Messinian boundary (7.12 Ma) while Opdyke et al. (1997) place the biostratigraphic boundary in a younger position (below the base of Chron C3An at about 6.7 Ma). Recent magnetostratigraphic and biostratigraphic determinations along a continental section near Molina de Segura in the Fortuna Basin (Garcés et al., 1998) has enabled the estimation of the youngest position for the MN12/MN13 boundary within Chron C3Ar with an age of about $6.8 \mathrm{Ma}$.

The numerical dating on volcanic rocks from the Fortuna Basin includes the Los Cabezos Negros lamproite exposure located south of the Fortuna village which is dated at $6.1 \pm 0.3 \mathrm{Ma}$ (Bellon et al., 1983). The lamproites are located at the base of the Rambla Salada Gypsum (Los Cabezos Negros section,
CN, Fig. 2). The referred age for the lamproites at Los Cabezos Negros is similar to the K/Ar radiometric dating obtained in the volcanic edifices from the Barqueros zone in the southwest part of the basin, $6.2 \pm 0.3$ to $7.0 \pm 0.3 \mathrm{Ma}$ (Montenat et al., 1975). Furthermore, Lukowski (1987) also described a volcanosedimentary level within the base of the Rambla Salada Gypsum and, thus, equivalent to the stratigraphic position of the Los Cabezos Negros lamproite. Recent observations in these lamproites and in the country rock (Playà, 1998; D. Gimeno and E. Playà, in prep.) indicate that the volcanic emplacement took place under a thin and soft sediment layer. Therefore, the volcanic rocks are thought to be almost coeval with the country rock sedimentation. However, there seems to be some incompatibility 


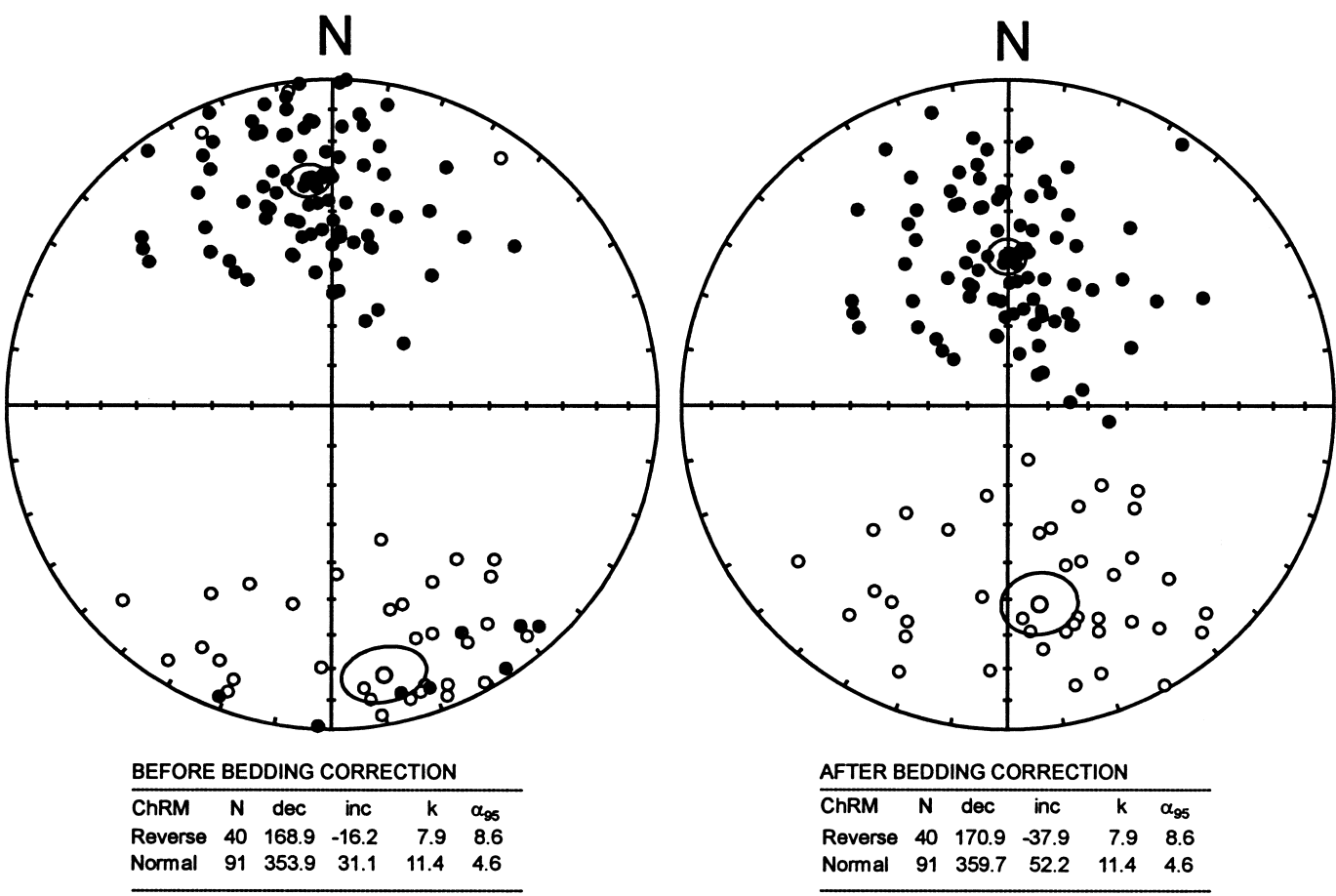

Fig. 8. Equal-area projection and Fisher statistics of the reliable ChRM directions before (in-situ) and after bedding correction. The 95\% confidence ellipse for the normal and reverse mean directions is indicated.

with the available radiometric datings and the derived age of the La Casa del Acero mammal site (MN12 biozone), given the slightly younger stratigraphic position of the latter (Fig. 2).

\subsection{Correlation to the GPTS}

Despite the slight discrepancy between the biostratigraphic constraint of the La Casa del Acero mammal site and the numerical dating on the volcanic rocks, we can confidently expect the base of the Rambla Salada Gypsum to be located somewhere in the Messinian and to be older than about $6 \mathrm{Ma}$ (Fig. 9). Further chronostratigraphic constraints are provided by a recent study in the Molina de Segura and Librilla areas in the southwest part of the Fortuna Basin (Garcés et al., 1998). These authors correlate the retrieved magnetostratigraphies in the mammalbearing alluvial-fan to fan-delta sequences that overlie the evaporites to the late Turolian (Messinian). In their Molina de Segura section Chron C3r is unambiguously identified in the upper part of the thick section whilst the older C3An and C3Ar chrons are recognised below and still within detrital facies that overlie the evaporites.

Given all the aforementioned constraints we can positively consider the upper normal magnetozone in the Río Chicamo section (N3, Fig. 9) to be older than Chron C3r. The more conservative correlation scheme to the GPTS (trial A in Fig. 9.) places the Rambla Salada Gypsum (N2-R2-N3 magnetozones) to Chron C3An, the R1 magnetozone in the Chicamo Cycles correlating with Chron C3Ar, and the N1 magnetozone in the Chicamo Gypsum correlating with Chron $\mathrm{C} 3 \mathrm{Bn}$. The implications of the correlation scheme A are: (1) all the evaporites in the $\mathrm{CH}$ section will be lower Messinian; and (2) the La Casa del Acero mammal site will be compatible with the youngest position of the MN12 biozone at the base of Chron C3An.2n as suggested in Opdyke et al. (1997). A second correlation scheme (trial B, Fig. 9) places the Chicamo Cycles at the top of Chron C3Br and the Rambla Salada Gypsum would correspond to chrons C3Bn to C3An.2n. The implications of 


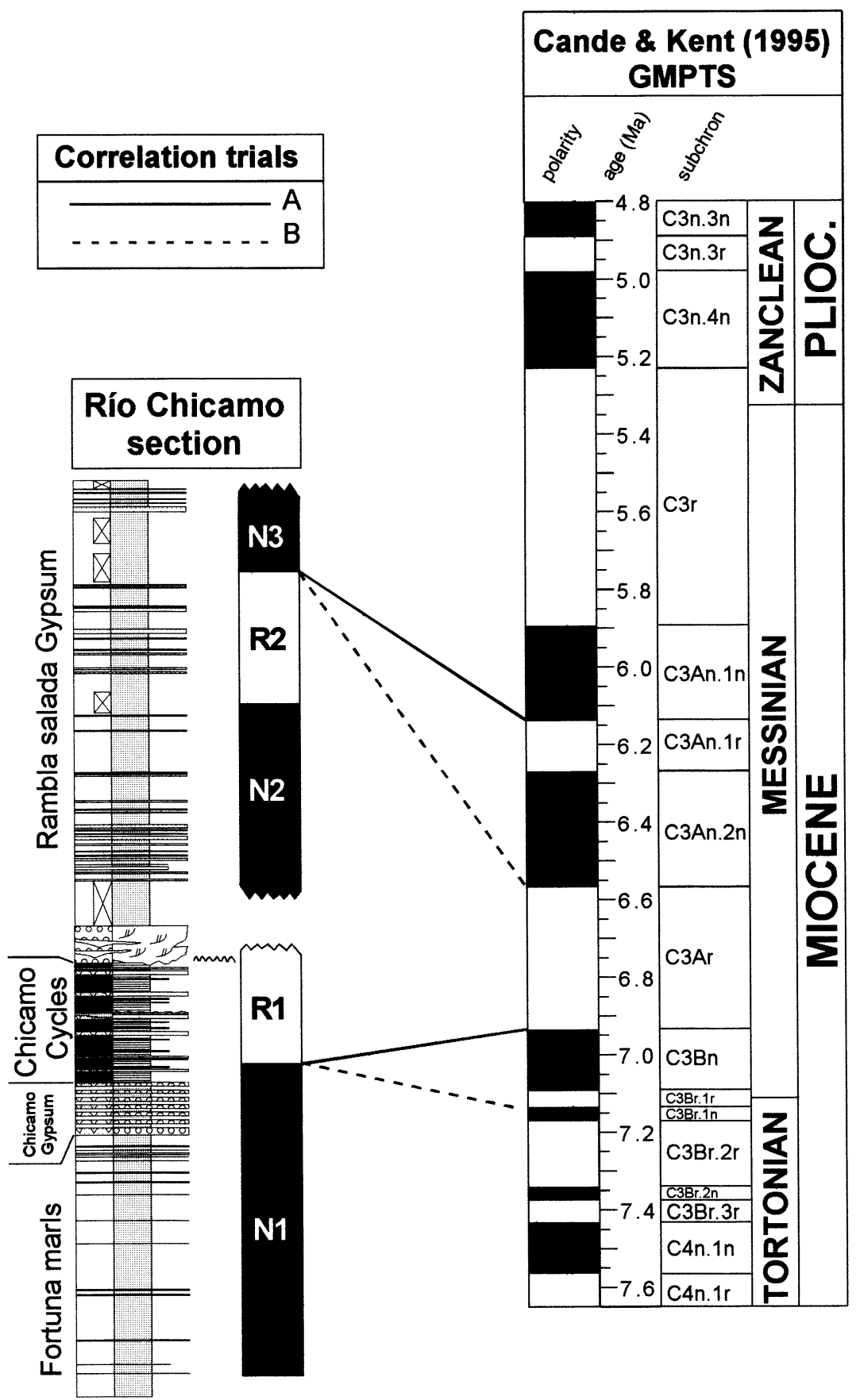

Fig. 9. Correlation schemes of the Río Chicamo section to the GPTS (GMPTS after Cande and Kent, 1995).

scheme B are: (1) the upper part of the Fortuna Marl Formation and the Chicamo Gypsum will be upper Tortonian whilst the Chicamo Cycles will mark the
$\mathrm{T} / \mathrm{M}$ transition; (2) the Casa del Acero site will be located at the base of the Messinian which is compatible with the different estimates for the age of 
MN12; and (3) the Los Cabezos Negros lamproites, in accordance with the numerical dating of Bellon et al. (1983), will be clearly younger $(\sim 1 \mathrm{Ma})$ than the country rock. However, the latter point seems to be at odds with the local presence of volcanic flows, piperites and other effusive structures that suggest a contemporaneity between volcanic rocks and country sediments.

The two correlation schemes presented here are the two more reasonable options although other more cumbersome correlations could be put forward. Nevertheless, one of the main implications of any possible correlation is that the marine evaporitic succession (Chicamo Cycles and Ribera Gypsum basically) from the Fortuna Basin is older than the evaporites from the Sorbas and Caltanissetta Basin (Gautier et al., 1994).

\subsection{The Upper Miocene evaporitic record in the Betic margin: insights to processes leading to the 'Messinian Salinity Crisis'}

The forcing mechanisms that led to the 'Messinian Salinity Crisis' in the Mediterranean are the interaction of tectonism, glacio-eustatic changes and local climate (Rouchy and Saint-Martin, 1992). The different time scales at which these mechanism operate and the prevalence or importance of either one of them in any particular region are critical for the understanding of the latest Neogene events recorded in the different basins. The tectonic convergence between Africa and Europe, causing the closure of the Iberian and Rifian Seaways, is perhaps the main driving factor that set the stage for the salinity crisis in addition to a climatic trend toward increased aridity and continentality. However, it is reasonable to think that the deformation processes resulting in the mountain building along the Betic Cordillera could act as an 'enhancing' factor for the late Neogene stagnation in the different Betic intramontane basins. The more marginal basins could potentially be the more sensitive ones to such an effect. The integrated biostratigraphic and magnetostratigraphic study in the intramontane Lorca Basin (Dinarès-Turell et al., 1998) suggest that the diatomitic-evaporitic (Tripoli Unit) and upper evaporitic (Halite Unit and Serrata Gypsum Unit) units are likely framed in time with the corresponding units of the 'Messinian Salinity Crisis' (i.e. the Serrata Gypsum Unit corresponds to Chron C3r). In detail, however, Rouchy et al. (1998) have recently showed how the marginal position of the Lorca Basin and local tectonics amplified the restriction prior to and during the salinity crisis (precursor gypsum layers, diagenesis related to both anoxia and hypersaline conditions, early continentalisation).

The data obtained in this study in the Fortuna Basin strongly suggest a diachroneity between the local evaporitic sedimentation in the Fortuna Basin with respect to the Sorbas Basin and the Sicilian counterpart. In the Fortuna Basin, evaporitic sedimentation starts earlier as a consequence of the local tectonically controlled dynamics (bathymetry) reinforcing possible relative sea level fluctuations. The alternation of several evaporitic packages with differentiated sulphur isotopic signature and the presence of interbedded diatomites indicate that the Fortuna Basin was periodically restricted and reflooded by marine waters. The diachronism of the evaporitic Upper Miocene sedimentation in the Mediterranean region was put forward by Rouchy (1982) and has been documented recently for the Lorca Basin (Rouchy et al., 1998). Butler et al. (1995) have suggested this feature for the different Sicilian basins and the central Mediterranean basin. Yet, the data presented here for the Fortuna Basin clearly strengthen the idea of diachroneity of the onset of evaporitic sedimentation along the Betic intramontane basins.

\section{Conclusions}

The magnetostratigraphic study of the $240 \mathrm{~m}$ thick Río Chicamo section has provided for the first time in the Fortuna Basin a direct chronological framework for the evaporites and related sediments in the basin. The five magnetozones recorded along the studied section can be matched to the GPTS following either of two alternative correlation schemes that constrain the evaporitic sedimentation between chrons $\mathrm{C} 3 \mathrm{Bn}$ and $\mathrm{C} 3 \mathrm{An} .1 \mathrm{n}$ or between $\mathrm{C} 3 \mathrm{Br} .1 \mathrm{n}$ and C3An.2n, respectively. The established chronology allows a direct comparison with previously established chronologies in other Mediterranean basins and constrain the Late Miocene evolution in the western Mediterranean as follows. 
(a) The mixed (marine-continental) evaporite deposition in the basin initiated either during the late Tortonian or around the Tortonian-Messinian boundary $(\mathrm{T} / \mathrm{M})$ whilst the overlying marine evaporite units (the diatomite-gypsum Chicamo Cycles and the Ribera Gypsum) were deposited either around the $\mathrm{T} / \mathrm{M}$ transition or during the lower Messinian. Thus, the two alternative correlation schemes indicate that the marine evaporites of the Fortuna Basin are older than the marine evaporites of the Sorbas Basin (Almeria, southeast Spain) and the Caltanissetta Basin (central Sicily) which are assigned to Chron C3r by Gautier et al. (1994).

(b) Among the various intramontane Neogene basins in the eastern Betics (southeast Spain), the Fortuna Basin recorded the earliest marine and marine-related evaporitic sedimentation in response to local structural controls. This sedimentation preceded the main phase of the salinity crisis (late Messinian), thus emphasising the diachronism of the onset of the marine evaporite/diatomite deposition throughout the Mediterranean region.

\section{Acknowledgements}

This study has been supported by the Spanish project DGICYT PB94-0082. J.D.-T. acknowledges an EU 'Marie Curie' fellowship (ERB4001 GT956999). M. Garcés and W. Krijgsman are thanked for sharing their work in the Fortuna Basin in an early stage and for stimulating discussion. We are also grateful to reviewers E. McClelland and J.E.T. Channell.

\section{References}

Agustí, J., Moyà-Solà, S., Gibert, J., Guillén, J., Labrador, M., 1985. Nuevos datos sobre la bioestratigrafía del Neógeno continental de Murcia. Paleontol. Evol. 18, 83-93.

Bellon, H., Bordet, P., Montenat, C., 1983. Chronologie du magmatisme néogène des Cordillières bétiques (Espagne méridionales). Bull. Soc. Géol. Fr. 7 (25) (2), 205-217.

Butler, R.W.H., Likorish, W.H., Grasso, M., Pedley, H.M., Ramberti, L., 1995. Tectonics and sequence stratigraphy in Messinian basins, Sicily: constraints on the initiation and termination of the Mediterranean salinity crisis. Geol. Soc. Am. Bull. 107, 425-439.

Butler, R.W.H., McClelland, E., Jones, R.E., 1999. Calibrating the duration and timing of the Messinian Salinity Crisis in the Mediterranean: linked tectono-climatic signals in thrust-top basins of Sicily. In: Unravelling Tectonic and Climatic Signals in Sedimentary Successions. Geol. Soc. London Spec. Publ. (in press).

Cande, S.C., Kent, D.V., 1995. Revised calibration of the geomagnetic polarity timescale for the Late Cretaceous and Cenozoic. J. Geophys. Res. 100, 6093-6095.

Cita, M.B., Wright, R.C., Ryan, W.B.F., Longinelli, A., 1978. Messinian paleoenvironments. Init. Rep. DSDP 42A, 10031035.

De Smet, M.E.M., 1984. Investigations of the Crevillente Fault Zone and Its Role in the Tectogenesis of the Betic Cordilleras, Southern Spain. Free University Press, Amsterdam, 174 pp.

Dinarès-Turell, J., Alfaro, P., Soria, J., 1995. A deformed Pliocene-Quaternary alluvial and red paleosol succession in the eastern Betics: paleomagnetic, rock-magnetic and sedimentological pilot study. Stud. Geophys. Geod. 39, 405-419.

Dinarès-Turell, J., Sprovieri, R., Caruso, A., Gomis-Coll, E., Di Stefano, E., Pueyo, J.J., Rouchy, J.M., Taberner, C., 1998. Preliminary integrated magnetostratigraphic and biostratigraphic correlation in the Miocene Lorca Basin (Murcia, SE Spain). Acta Geol. Hisp. (in press).

d'Onofrio, S., Gianelli, L., Iaccarino, S., Morlotti, E., Romeo, E., Salvatorini, G., Sampo, M., Sprovieri, R., 1975. Planktonic foraminifera of the Upper Miocene from some Italian sections and the problem of the lower boundary of the Messinian. Boll. Soc. Paleontol. Ital. 14, 177-196.

Garcés, M., Krijgsman, W., Agustí, J., 1998. Chronology of the late Turolian deposits of the Fortuna basin (SE Spain): implications for the Messinian evolution of the eastern Betics. Earth Planet. Sci. Lett. 163, 69-81.

Gautier, F., Clauzon, G., Suc, J.P., Cravatte, J., Violanti, D., 1994. Age et durée de la crise de salinité messinienne. C. R. Acad. Sci. 2 (318), 1103-1109.

Gauyau, F., Bayer, R., Bousquet, J.C., Lachaud, J.C., Lesquer, A., Montenat, C., 1977. Le prolongement de l'accident d'Alhama de Murcia entre Murcia et Alicante (Espagne méridionale). Résultats d'une étude géophysique. Bull. Soc. Géol. Fr. 19, 623-629.

Hernandez, J., de Larauziere, F.D., Bolze, J., Bordet, P., 1987. Le magmatisme néogène bético-rifain et le couloir de décrochement 'trans-Alboran'. Bull. Soc. Géol. Fr. 8 (3) (2), 257267.

Hilgen, F.J., Krijgsman, W., Langereis, C.G., Lourens, L.J., Santarelli, A., Zachariasse, W.J., 1995. Extending the astronomical (polarity) timescale into the Miocene. Earth Planet. Sci. Lett. 136, 495-510.

Hodell, D.A., Benson, R.H., Kent, D.V., Boersma, A., Rakic-El Bied, K., 1994. Magnetostratigraphic, biostratigraphic, and stable isotope stratigraphy of an Upper Miocene drill core from the Salé Briqueterie (northwest Marocco): a high-resolution chronology for the Messinian stage. Paleoceanography 9, 835-855.

Hsü, K.J., Montadert, L., Bernouilli, D., Cita, M.B., Erikson, A., Garrison, R.G., Kidd, R.B., Mélières, F., Müller, C., Wright, 
R., 1978. History of the Mediterranean salinity crisis. Init. Rep. DSDP 42A, 1053-1078.

Iaccarino, S., 1985. Mediterranean Miocene and Pliocene planktic foraminifera. In: Bolli, H.M., Saunders, J.B., PerchNielsen, K. (Eds.), Plankton Stratigraphy. Cambridge Univ. Press, Cambridge, pp. 283-314.

Kastens, K.A., 1992. Did glacio-eustatic sea level drop trigger the Messinian salinity crisis? New evidence from Ocean Drilling Program site 654 in the Tyrrhenian Sea. Paleoceanography 7, 333-356.

Kirschvink, J.L., 1980. The least-square line and plane and analysis of paleomagnetic data. Geophys. J. R. Astron. Soc. 62, 699-718.

Krijgsman, W., Hilgen, F.J., Langereis, C.G., Santarelli, A., Zachariasse, W.J., 1996. Late Miocene magnetostratigraphy, biostratigraphy and cyclostratigraphy in the Mediterranean. Earth Planet. Sci. Lett. 136, 475-494.

Langereis, C.L., Dekkers, M.J., 1992. Paleomagnetism and rock magnetism of the Tortonian-Messinian boundary stratotype at Falconara (Sicily). Phys. Earth Planet. Inter. 71, 100-111.

Lukowski, P., 1987. Evolution tectonosédimentaire du bassin Néogène de Fortuna (Cordillères bétiques orientales, Espagne). Univ. de Paris Sud, 403 pp.

Lukowski, P., Poisson, A., 1990. Le bassin de Fortuna. Doc. Trav. IGAL 12-13, 303-311.

Lukowski, P., Wernli, R., Poisson, A., 1988. Mise en évidence de l'importance des dépôts messiniens dans le bassin Miocène de Fortuna (Province de Murcia, Espagne). C. R. Acad. Sci. Paris 307, 941-947.

McClelland, E., Finegan, B., Butler, R.W.H., 1996. A magnetostratigraphic study of the onset of the Mediterranean Messinian salinity crisis; Caltanissetta Basin, Sicily. In: Morris, A., Tarling, D.H. (Eds.), Palaeomagnetism and Tectonics of the Mediterranean Region. Geol. Soc. London Spec. Publ. 115, 205-217.

McFadden, P.L., McElhinny, M.W., 1990. Classification of the reversal test in paleomagnetism. Geophys. J. Int. 103, 725729.

Montenat, C., 1973a. Les formations néogènes et quaternaires du levante espagnol (province d'Alicante et de Murcie). Thèse Sci., Univ. Orsay, 1170 pp.

Montenat, C., 1973b. Le Miocène terminal des chaînes bétiques (Espagne méridionale). Esquisse paléogéographique. Proc. K. Ned. Akad. Wetensch. B, 180-187.

Montenat, C., 1977. Les bassins néogènes du Levant d'Alicante et de Murcia (Cordillères bétiques orientales, Espagne). Stratigraphie, paléogéographie et évolution dynamique. Doc. Lab. Géol. Fac. Sci. Lyon 69, 345 pp.

Montenat, C., Ott d'Estevou, P., 1990. Eastern Betic Neogene basins - a review. Doc. Trav. IGAL 12-13, 9-15.

Montenat, C., Thaler, L., van Couvering, J.A., 1975. La faune de rongeurs de Librilla. Corrélations avec les formations marines du Miocène terminal et les datations radiométriques du volcanisme de Barqueros (Province de Murcia, Espagne méridional). C. R. Acad. Sci. Paris 281, 519-522.

Montenat, C., Ott d'Estevou, P., Rodríguez-Fernández, J., Sanz de Galdeano, C., 1990. Geodynamic evolution of the Betic
Neogene intramontane basins (S and SE Spain). Paleontol. Evol. 2, 5-59.

Müller, D.W., 1986, Die Salinitätskrise im Messinian (spätes Miozan) del Becken von Fortuna und Sorbas (Südost-Spanien). Ph.D. Thesis, R.T.H. Zürich, 183 pp.

Müller, D.W., Hsü, K.J., 1987. Event stratigraphy and paleoceanography in the Fortuna basin (southeast Spain): a scenario for the Messinian salinity crisis. Paleoceanography 6, 679696.

Müller, D.W., Schrader, H., 1989. Diatoms of the Fortuna basin, Southwest Spain: evidence for the intra-Messinian inundation. Paleoceanography 4, 75-86.

Opdyke, N.D., Mein, P., Lindsay, E., Perez-González, A., Moissenet, E., Norton, V.L., 1997. Continental deposits, magnetostratigraphy and vertebrate paleontology, late Neogene of Eastern Spain. Palaeogeogr., Palaeoclimatol., Palaeoecol. 133, 129-148.

Ortí, F., García-Veigas, J., Rosell, L., Rouchy, J.M., Inglès, M., Gimeno, D., Kasprzyk, A., Playà, E., 1993. Correlación litoestratigráfica de las evaporitas mesinienses en las cuencas de Lorca y Fortuna (Murcia). Geogaceta 14, 98-101.

Parés, J.M., Dinarès-Turell, J., 1993. Magnetic fabric in two sedimentary rock-types from the southern Pyrenees. J. Geomagn. Geoelectr. 45, 193-205.

Playà, E., 1998. Les evaporites de les conques bétiques marginals (Fortuna-Lorca, Miocè superior): Comparació amb altres conques mediterrànies. PhD. Thesis, Univ. Barcelona, 248 pp.

Playà, E., Ortí, F., Rosell, L., 1995. Composición isotópica de los yesos messinienses de la cuenca de Fortuna (Murcia): implicaciones sedimentológicas. Geogaceta 18, 122-125.

Rouchy, J.M., 1982. La génèse des évaporites messiniennes de Méditerranée. Mém. Mus. Nat. Hist. Nat. L, 267 pp.

Rouchy, J.M., Pierre, C., 1979. Données sédimentologiques et isotopiques sur les gypses des séries évaporitiques messiniennes d'Espagne méridionale et de Chypre. Rev. Géol. Dyn. Géogr. Phys. 21, 267-280.

Rouchy, J.M., Saint-Martin, J.P., 1992. Late Miocene events in the Mediterranean as recorded by carbonate-evaporite relations. Geology 20, 629-632.

Rouchy, J.M., Taberner, C., Blanc-Valleron, M.M., Sprovieri, R., Russell, M., Pierre, C., Di Stefano, E., Pueyo, J.J., Caruso, A., Dinarès-Turrell, J., Grimalt, J., Gomis-Coll, E., Cespuglio, G., Wolff, G., Ditchfield, P., Pestrea, S., Marshall, J., CombourieuNebout, N., Santisteban, C., 1998. Sedimentary and diagenetic markers of the restriction in a marine basin: the Lorca basin (SE Spain) during the Messinian. Sediment. Geol. 121, 23-55.

Santisteban, C., 1981. Petrología y sedimentología de los materiales del Mioceno superior de la cuenca de Fortuna (Murcia), a la luz de la 'teoría de la crisis de salinidad'. Thesis Doct., Univ. Barcelona, 722 pp.

Sanz de Galdeano, C., 1990. Geological evolution of the Betic Cordilleras in the Western Mediterranean, Miocene to present. Tectonophysics 172, 107-119.

Sanz de Galdeano, C., Vera, J.A., 1992. Stratigraphic record and palaeogeographical context of the Neogene basins in the Betic Cordillera, Spain. Basin Res. 4, 21-36.

Sierro, F.J., Flores, J.A., Civis, J., Zamarreño, I., Vázquez, A., 
Santisteban, C., Porta, J., 1992. Las margas de Fortuna: bioestratigrafía y caracterización paleoceanográfica, III Congreso Geológico de España, VIII Congreso Latinoamericano de Geología, I, pp. 222-226.

Shackleton, N.J., Hall, M.A., Pate, D., 1995. Pliocene stable isotope stratigraphy of ODP site 846. Proc. ODP Sci. Res. 138.

Steininger, F.F., Berggren, W.B., Kent, D.V., Bernor, R.L., Sen, S., Agustí, J., 1996. Circum-Mediterranean Neogene (Miocene and Pliocene) marine-continental chronologic correlations of European mammal units and zones. In: Bernor,
R.L., Fahlbusch, V., Rietschel, S. (Eds.), Later Neogene European Biotic Evolution and Stratigraphic Correlation. Columbia Press, New York, pp. 7-46.

Utrilla, R., 1989. Les composicions isotòpiques $\left(\delta^{18} \mathrm{O}, \delta^{34} \mathrm{~S}\right)$ del sulfat, com a indicadors de l'origen de les evaporites del Mesozoic i del Cenozoic de la península Ibérica I les Illes Balears. PhD. Thesis, Univ. Barcelona, 276 pp.

Zijderveld, J.D.A., 1967. AC demagnetization of rock: analysis of results. In: Collinson, D.W., Creer, K.M., Runcorn, S.K. (Eds.), Methods in Paleomagnetism. Elsevier, Amsterdam, pp. 254-286. 